\title{
The emergence of agroecological practices on agropastoral dairy farms in the face of changing demand from dairies
}

\author{
Arielle Vidal, Amandine Lurette, Marie-Odile Nozières-Petit, Éric Vall, Charles- \\ Henri Moulin
}

SELMET, Université de Montpellier, Cirad/Inra/Montpellier SupAgro, 2 Place Pierre Viala, F-34060 Montpellier Cedex 1 (France).E-mail: contact@ariellevidal.com

Received 14 May 2019, accepted 7 May 2020, available online 28 May 2020.

This article is distributed under the terms and conditions of the CC-BY License (http://creativecommons.org/licenses/by/4.0)

Description of the subject. Today, the dairy sector is facing economic, social and environmental challenges. Agroecology seems to be one way of meeting those challenges. However, dairy market demand in terms of volume and supply periods may not be in line with an agroecological transition. Breeders must respond to the production conditions fixed by dairies.

Objectives. We analyzed to what extent dairy farming practices are changing in two agropastoral territories after a change in the dairy process or supply period, and whether changes in practices induce a stronger uptake of agroecological practices or, on the contrary, a shift towards more conventional intensification of those practices. We were thus able to see if and how these livestock farming system dynamics contribute to and fashion agroecological transition in dairy production, in response to changes in local contexts.

Method. To highlight the evolution of breeders' practices, we interviewed 41 dairy ewe farmers in the South of France and dairy cattle farmers in Western Burkina Faso. We then proposed a normative approach to evaluate to what extent changes in practices corresponded to an agroecological transition. For that purpose, we proposed a grid to analyze local practices in combination with agroecological principles. We evaluated practices before and after changes to the supply period or the dairy market.

Results. In each of the territories studied, four trajectories emerged, some of which were part of an agroecological transition. The results showed that the market plays an important role as a driver of transition, in particular in situations of organic production, or limited access to inputs. Other drivers, such as resource management schemes, lead to changes in practices on rangelands towards a reduced use of pastoral resources.

Conclusions. In these highly contrasting contexts with different issues, such as food security and land accessibility, farmers bring into play practices according to agroecological principles that appear to respond to the local situation.

Keywords. Agroecology, ruminants, farming system, agropastoral system, milk, Mediterranean, West Africa.

L'évolution des pratiques vers une transition agroécologique : un défi pour les producteurs laitiers mobilisant des systèmes agro-pastoraux

Description du sujet. Aujourd'hui, le secteur laitier est confronté à des défis économiques, sociaux et environnementaux. L'agroécologie semble être une voie pour répondre à ces défis. Cependant, les injonctions du marché laitier en matière de volume et de période d'approvisionnement peuvent ne pas aller dans le sens d'une transition agroécologique. Les éleveurs doivent répondre aux conditions de production fixées par les laiteries.

Objectifs. Nous avons analysé dans quelle mesure les pratiques de production laitière évoluent dans deux territoires agropastoraux après un changement de laiterie ou de période d'approvisionnement et si les changements de pratiques sont en phase avec les principes qui sous-tendent l'agroécologie ou, au contraire, avec une intensification plus conventionnelle de ces pratiques. Nous avons ainsi pu voir si et comment ces dynamiques d'élevage contribuent et façonnent la transition agroécologique dans ces territoires, en réponse aux changements des contextes locaux.

Méthode. Pour mettre en lumière les trajectoires de pratiques des éleveurs, nous avons réalisé des entretiens auprès de 41 producteurs de lait de brebis dans le Sud de la France et de lait de vache dans l'Ouest du Burkina Faso. Ensuite, nous proposons une approche normative pour évaluer dans quelle mesure les trajectoires de pratiques correspondent à une transition agroécologique. Pour cela, nous proposons une grille d'analyse des pratiques locales en lien avec les principes de l'agroécologie. Nous évaluons les pratiques avant et après les changements de période d'approvisionnement ou de laiterie.

Résultats. Dans chacun des territoires d'étude ont émergé quatre trajectoires dont certaines sont en phase avec les principes de l'agroécologie. Les résultats montrent que le marché joue un rôle important en tant que moteur de la transition dans 
les situations de production en agriculture biologique ou de faible accès aux intrants. D'autres facteurs conduisent à des changements de pratiques de pâturages et à une réduction de l'utilisation des parcours.

Conclusions. Dans ces contextes très contrastés, des questions telles que la sécurité alimentaire et l'accessibilité des terres conduisent à mobiliser des pratiques en lien avec les principes agroécologiques qui semblent répondre à la situation locale.

Mots-clés. Agroécologie, ruminant, système d'élevage, agropastoralisme, lait, Méditerranée, Ouest de l'Afrique.

\section{INTRODUCTION}

On a global scale, dairy farming displays a wide diversity of systems. The dairy sector is facing numerous challenges. It is involved in world food security: production is increasing to satisfy rising consumption. It provides income for dairy farmers and maintains economic activities in rural zones, but livestock farming is criticized for its adverse environmental effects (FAO, 2006; Gerber et al., 2013). These challenges take various forms in different regions of the world. In developed countries, intensive livestock farming also raises consumer health issues, notably through the development of resistance to antibiotics (Stanton, 2013). In developing countries, such as some African countries, consumption is outstripping production. To guarantee national food security, it is necessary to increase the quantity of food by relying on local resources in order to preserve the environment and the health of populations (Touzard \& Temple, 2012; Temple et al., 2015).

Nevertheless, livestock offers the potential to contribute to agroecological transition. Dumont et al. (2013), adapted from Altieri (2002), proposed the following five principles to characterize the agroecological dimension of livestock farming systems:

- integrated healthcare management;

- reduced inputs for production requirements;

- reduced pollutants through optimized metabolic functions;

- greater diversity to strengthen resilience;

- preservation of biodiversity.

Hence, the question of whether the dynamics of change in those agropastoral dairy systems driven by the dairy process reinforce agroecological practices, or lead to conventional intensification, remains pending. Work on livestock agroecology mostly focuses on mixed crop-livestock farming systems (Bonaudo et al., 2014). These five principles of adapted livestock practices seem to be applied, at least in part, by pastoral livestock farmers. In particular, in the case of pastoralism, interactions between animals and their environment are strong. Breeders rely on diverse species and locally adapted breeds, and on multiple forms of mobility (seasonal, commercial, labor) (Gliessman \& Engles, 2015; Soussana et al., 2018). In tropical areas and in the Mediterranean, a large share of milk production still comes from small farms using rangelands, in agropastoral systems. Agropastoral farming uses a range of feed resources, derived from spontaneous vegetation or recycled crop residues, and from local ecological knowledge (Gobindram et al., 2018). However, as highlighted by Jouven (2016), the reality is more complex, as grazing practices are only one component of livestock and cropping practices.

Looking beyond the status of a system at a given time, we need to consider how the whole system evolves. This evolution can be qualified in terms of implementing practices seen from an agroecological perspective, i.e. to what extent those practices make use, or not, of ecological levers to support production. Indeed, in both Europe and Africa, farmers are changing their farms, notably by implementing innovations having different origins, such as farmers, professional groups, technical support systems, policies (Ingrand et al., 2014). Vall et al. (2014) described changes and innovations in Burkinese livestock systems receiving technical support (government dairies, milk powder taxation) that encouraged breeders to use crossbreeding and artificial insemination, and to produce forage and purchase feed in the dry season. The sociotechnical regime in which agriculture finds itself makes alternative innovations difficult, although they do exist (Stassart et al., 2012). Emerging of innovant practices (Meynard, 2017; Lacombe et al., 2018) permit to rethink of farming systems towards agroecological transition (Tittonell, 2014).

We analysed to what extent dairy farming practices were changing in two agropastoral territories after a change in the dairy process or supply period, and whether changes in practices induced a stronger uptake of agroecological practices or, on the contrary, a shift towards more conventional intensification of those practices. We were thus able to see if and how these livestock farming system dynamics contributed to and fashioned agroecological transition in those territories, in response to changes in local contexts.

\section{MATERIALS AND METHODS}

\subsection{Description of the chosen territories}

Ewe breeding in the Grands Causses area of France. In the Grands Causses area of France (GCF) (Figure 1), the production of ewe's milk and its 


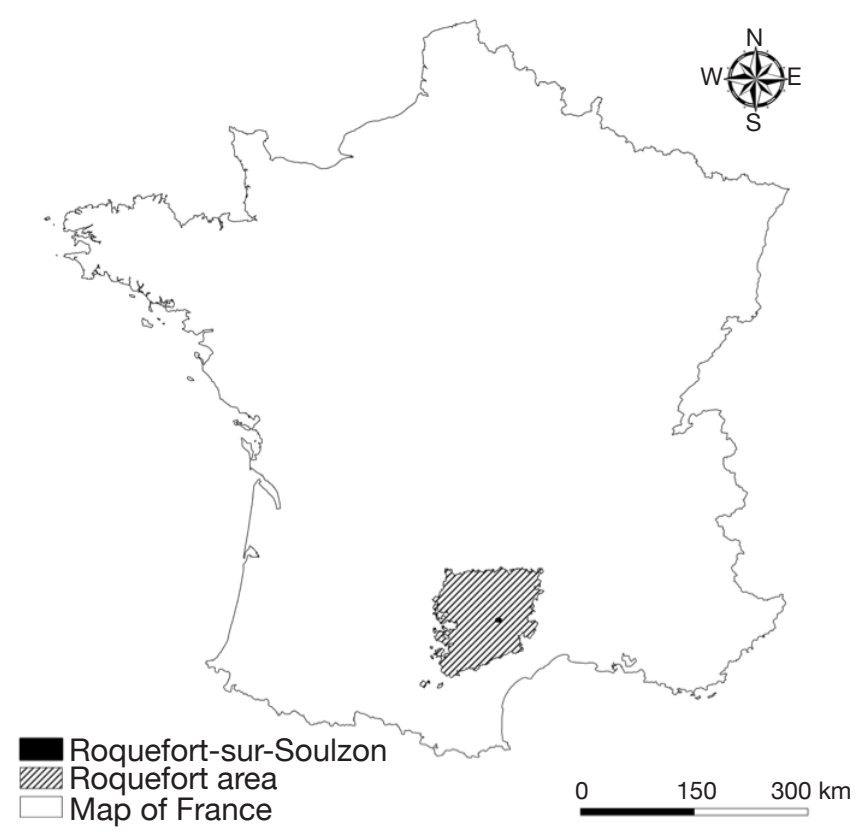

Figure 1. Geographical location of the roquefort cheese area in France (produced by Imad Shaqura) - Situation géographique du bassin de production de roquefort en France (réalisé par Imad Shaqura).

processing into Roquefort cheese have a long, shared history. Since 1925, roquefort cheese has benefited from protected designation of origin status. In 2014, technical organizations in the roquefort area were accompanying around $80 \%$ of dairy farmers, and $56 \%$ of the territory's dairy sheep farming systems were selfsufficient in fodder. Improving the genetic potential of ewes, coupled with appropriate feeding, increased milk production from an average of 210 litres per ewe in 2000 to an average of 239 litres per ewe in 2014. These extension services assisted dairy farmers by offering technical support (feed), technical/economic advice and genetic monitoring (Morin et al., 2016).

The dairies now collect milk all year round, seeking to stagger production on dairy farms. In the past, the soil and climatic conditions, in particular, fashioned the local livestock farming systems, with highly seasonal milk production (December to July). The milking period plays a role in structuring livestock systems, leading farmers to vary their feeding practices and use of pastoral resources (Quetier et al., 2005), depending on the production period. This change has led farmers to adopt different feeding strategies. Depending on the production period, the strategies differ, which has had an impact on feeding and grazing practices, particularly on the development and use made of pastoral resources. Livestock producers have adopted two main feeding strategies, based on fodder stocks and grazing (Quetier et al., 2005).
Some farmers have implemented different practices aimed at encouraging forage production adapted to drought and increasing the value of rangelands (Allézard et al., 2014; Magne et al., 2019). Other farmers have labelled their farms "organic", and then changed their dairy process to sell organic milk (Magne et al., 2019). Magne et al. (2019) characterized four types of livestock systems from these practices:

- economical systems producing over a short period of time by exploiting available local resources, limiting fodder and concentrates;

- breeders, whose objective is to produce milk on grass by exploiting undiversified productive fodder resources. These farmers buy protein concentrates to optimize the genetic potential of Lacaune ewes, but they are self-sufficient in fodder;

- farmers who produce organic sheep milk by making the best use of the diversity between animal and plant biological resources. They purchase concentrates and fodder;

- farmers who produce milk over a long period in winter and summer. They seek to optimize the use of available harvested fodder resources and to use pastoral areas in summer.

High milk production levels offset the purchase of protein concentrates. However, not all farmers have followed this movement.

Cow breeding in Western Burkina Faso. In the Western Burkina Faso (WBF) area (Figure 2), the authorities have been implementing programs to support milk production since the 1990s (Hamadou et al., 2008), by backing "public" dairies, which were subsequently privatized. At the same time, some private dairies also developed, and that model appeared to be more resilient (Duteurtre, 2007). These small dairies have an average processing capacity of 200 to 300 litres per day (Sib et al., 2017). Four producers supply 100 litres of milk per day on average. Including producers and collectors, the dairies that use local milk hire twice as many people as dairies that exclusively process powdered milk (Orasmaa, 2017).

Some initiatives to improve milk production, supported by state extension services, focused on fodder production, use of feed inputs, and crossing local animal populations with European breeds, by artificial insemination. With the depletion of available grazing areas, initially transhumant livestock farmers tended to become sedentary, but the uptake of techniques recommended by supervisors remained limited (Dongmo et al., 2012), with only one percent of breeders adopting intensification schemes (Hamadou et al., 2008). Intensified farms require high investments in buildings and equipment. They are generally managed by farmers who invest while maintaining 


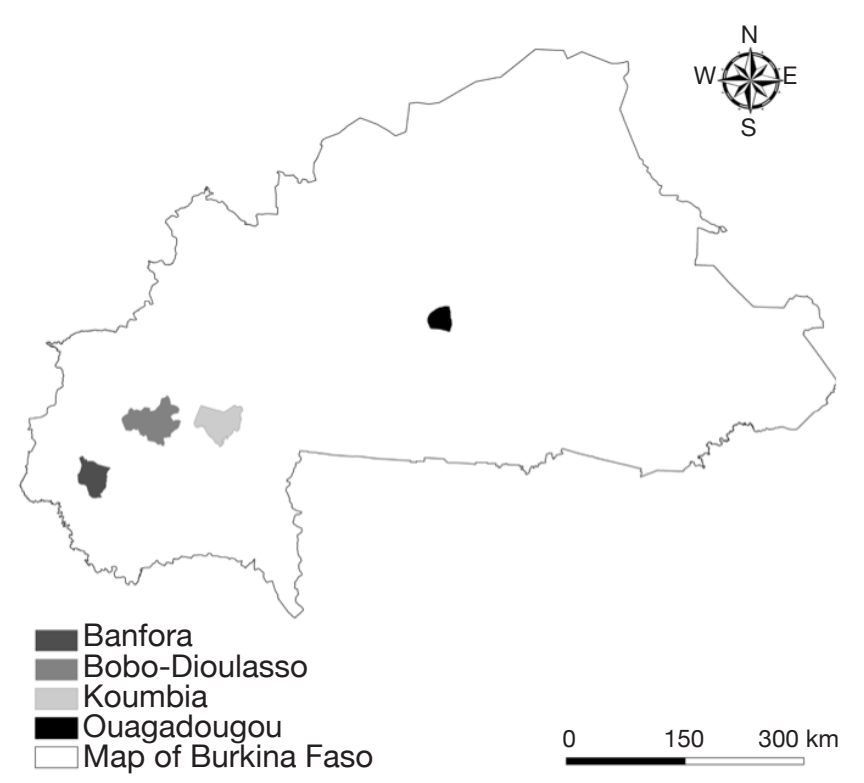

Figure 2. Geographical location of the farms studied in the areas around Bobo-Dioulasso, Koumbia and Banfora (produced by Imad Shaqura) - Situation géographique des élevages laitiers étudiés autour des communes de BoboDioulasso, Koumbia et Banfora (réalisé par Imad Shaqura).

another professional activity (tradesman, civil servant, vet). Agropastoral farming systems of 5-11 ha account for $7 \%$ of the production units, while pastoral farming systems, with less than 1 ha, remain in the majority (92\% of the production units) (Hamadou et al., 2008). Recently, Sib et al. (2017) described five types of dairy farming systems based on structural, functional and performance variables. Types 1 and 2 are low-input with suckler-cow farms, with high (T1) and medium (T2) pastoral inputs. $\mathrm{T} 1$ and $\mathrm{T} 2$ farms are characterized by a diet mostly based on grazed resources in all seasons, with a production level of less than 2 litres per cow per day, mainly for family consumption. Type 3 consists of suckler farms with an agropastoral orientation. These farmers make greater use of dry fodder and feed, which allows them to sell about 2 litres of milk per cow per day. Types 4 and 5 are specialized in milk production. The proportion of distributed fodder and concentrates in the ration is high all year round. Some have low use of green fodder (T4) and others have high use (T5). These farmers crossbreed dairy cows with improved genetic dairy potential, allowing them to sell 5-13 litres of milk per cow per day to dairies.

\subsection{Sampling}

The aim of the sampling process was to interview dairy farmers who had changed their practices to meet the demands of the dairies. We used a snowball sampling method, conventionally used in qualitative research in the social sciences (Goodman, 1961), turning to dairy farmer knowledge networks to identify people having made changes. Thus, sampling was not representative of the "population" of dairy farms in the two study areas, but maximized the diversity of changes in practices linked to demands from the dairies.

For the GCF area, through various professional networks, we identified a few dairy farmers who had changed their milking period, or their sales channel. Those farmers then informed us of other farmers who had made the same type of change. In order to make up the sample, we also sought to recruit farmers with a diversity of production (conventional or organic) and/or marketing schemes (milk sold to companies for Roquefort production or other manufacturing, or on-farm processing and short sales channels). In all, 21 dairy farmers were interviewed (Table 1).

For WBF, in the small agricultural regions of BoboDioulasso, Koumbia and Banfora, the producer groups identified three dairy farmers. The initial three farmers informed us of other farmers who had made changes in their sales channel and who now regularly sold milk to a dairy. Here too, we sought to recruit a sample of dairy farmers with diverse types of production and marketing schemes, according to the typology of Sib et al. (2017). At some point in their lives, all the farmers had sold milk to dairies and cultivated cereals for the family. A sample population of 20 farmers was established (Table 2).

\subsection{Data collection}

We carried out semi-directive interviews lasting from 1.5 to $3.5 \mathrm{~h}$ per farm. In Burkina Faso, an interpreter translated the interviews with the farmers. The first

Table 1. Structural description of the 21 farms surveyed in the Grands Causses territory (France) in 2017 Description de la structure des 21 exploitations agricoles enquêtées dans le territoire des Grands Causses (France).

\begin{tabular}{llll}
\hline & Minimum & Maximum & Average \\
\hline $\begin{array}{l}\text { Breeding dairy } \\
\text { sheep (head) }\end{array}$ & 200 & 750 & 415 \\
$\begin{array}{l}\text { Annual volume } \\
\text { produced (hl) }\end{array}$ & 350 & 2,200 & 860 \\
$\begin{array}{l}\text { Milk per ewe (l) } \\
\text { Arable areas (ha) }\end{array}$ & 125 & 325 & 214 \\
$\begin{array}{l}\text { Pastoral areas (ha) } \\
\text { Labour of associates }\end{array}$ & 1 & 195 & 95 \\
(FTE) & 60 & 5 & 240 \\
Hired labour (FTE) & 0.0 & 0.6 & 2.5 \\
\hline
\end{tabular}

FTE - ETP: full-time equivalent - équivalent temps plein. 
Table 2. Structural description of the 20 farms surveyed in the Western Burkina Faso territory in 2017 - Description de la structure des 20 exploitations agricoles enquêtées dans l'ouest du Burkina Faso.

\begin{tabular}{llll}
\hline & Minimum & Maximum & Average \\
\hline $\begin{array}{l}\text { Number of cattle } \\
\text { (head) }\end{array}$ & 11 & 125 & 46 \\
$\begin{array}{l}\text { Number of milking } \\
\text { cows (head) }\end{array}$ & 3 & 29 & 10 \\
$\begin{array}{l}\text { Annual volume } \\
\text { produced (1) }\end{array}$ & 367 & 12,012 & 4,505 \\
$\begin{array}{l}\text { Milk per cow (1) } \\
\text { Number of arable } \\
\text { hectares (ha) }\end{array}$ & 0 & 2,085 & 490 \\
$\begin{array}{l}\text { Family labour } \\
\text { (FTE) }\end{array}$ & 1 & 20 & 4.7 \\
$\begin{array}{l}\text { Family help, } \\
\text { number of people }\end{array}$ & 0 & 8 & 4 \\
$\begin{array}{l}\text { Hired labour, } \\
\text { number of people }\end{array}$ & 0 & 13 & 4 \\
\hline
\end{tabular}

FTE - ETP: full-time equivalent - équivalent temps plein.

part of the survey traced the history of the farm from the arrival of the current manager, with a particular focus on changes in practices. We collected data on herd management practices (reproduction, genetics, feeding), crop management (tillage, choice of varieties) and work schedules. The second part described the annual management of the livestock farm over the 2015-2016 (GCF) or 2016-2017 (WBF) period. We used an interview grid sheet to ensure topics were effectively covered with the farmer. We recorded the interviews with farmers in GCF, and took written notes during the interview, particularly in WBF.

\subsection{Analysis of changes in livestock practices}

Our objective was to highlight the change in farming practices over time after a change in demands from the dairies. To do this, we used a linear and a normative analysis of the trajectories (Capillon \& Tagaux al., 1984; Perrot et al., 1995). According to Moulin et al. (2008), two types of changes can be distinguished. Gradual changes, over several years, can occur without affecting the coherence of livestock management. In that case, we considered the farm to be in a period of stability. Other changes, mostly affecting practices and occurring over a short time span, affected the coherence of the livestock system. In this case, we considered the farm to be in a period of transformation. From this stability/transformation breakdown, we considered two periods for each farm (Figure 3). Between these two periods, the farmer made at least one change in sales channel and/or milking period. The first period (P1) corresponded to the period of stability before the changes. This period P1 was spread between 2000 and 2015, depending on the farm. The second period (P2) corresponded to farm functioning over the year preceding the survey: 2015-2016 for GCF, or 20162017 for WBF. In P2, the farm could therefore be in a period of stability or, conversely, in a period of transformation. Depending on the farm, the duration between $\mathrm{P} 1$ and $\mathrm{P} 2$ varied from 2 to 15 years.

Secondly, we analyzed changes in practices between those two periods covering the $2000-2017$ period. We did this by constructing variables (Tables 3 and 4 ) to characterize livestock farmer practices. The variables chosen were not uniform from one territory to the other, in order to take into account the livestock rearing context. We did not take into account practices that did not vary from one farmer to another in the sample. For instance, in GCF all farmers used the Lacaune breed. We qualified these types of practices based on the five agroecological principles. For GCF, we considered seven types of practices (Magne et al., 2010): health,

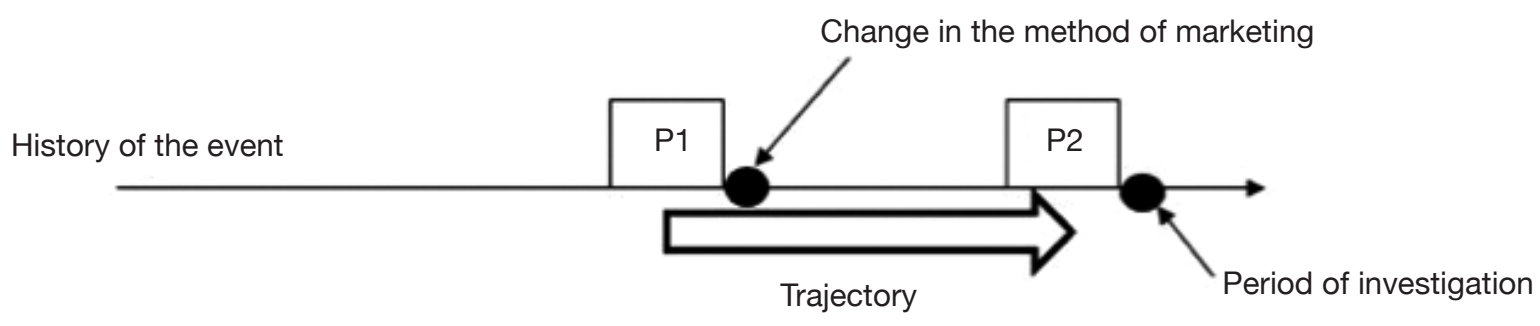

P1; Period1 Stability phase

P2; Period2 Stability or transformation phase

Figure 3. Schematic representation of the division between two periods - Représentation schématique du découpage effectué entre deux périodes. 


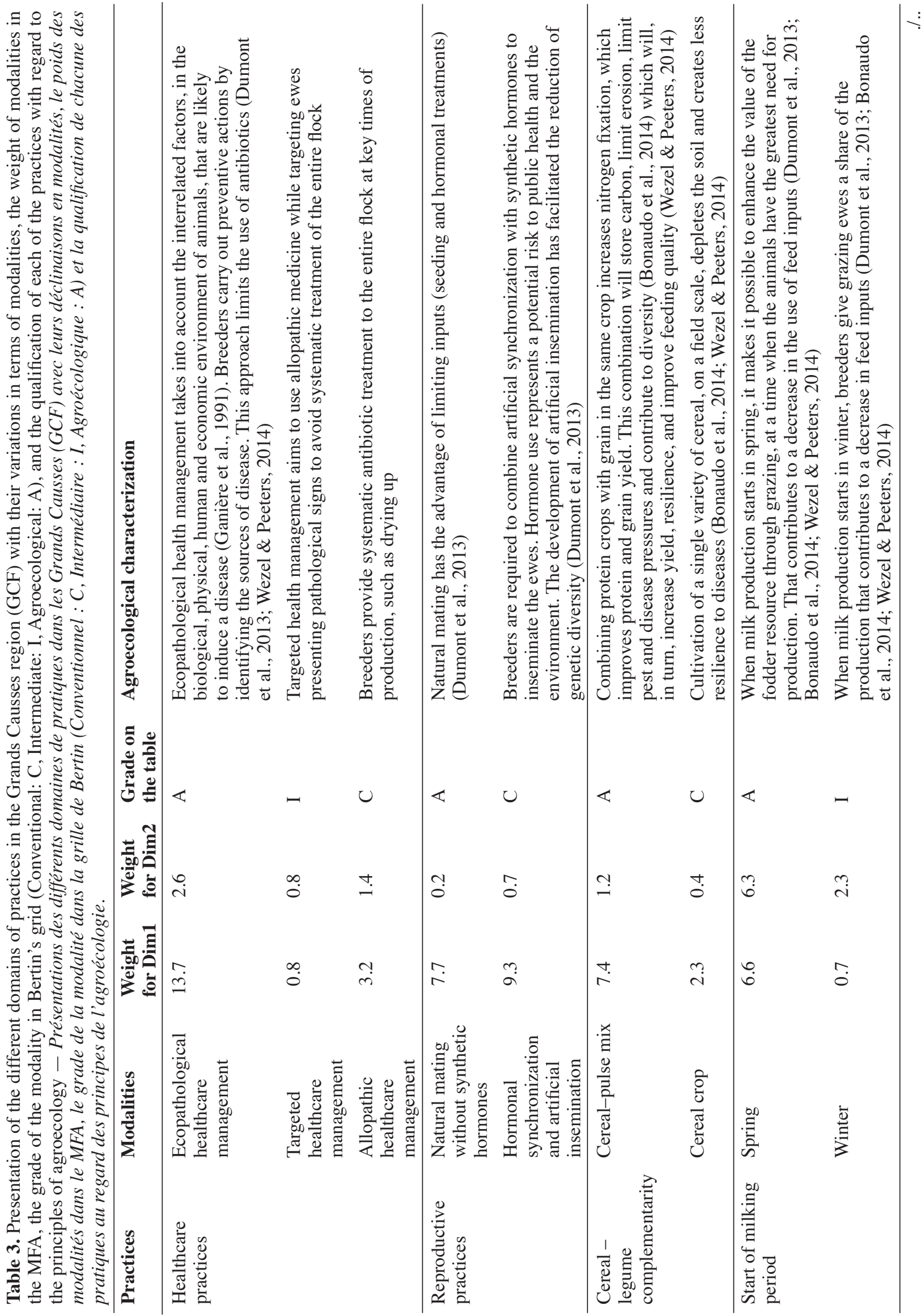




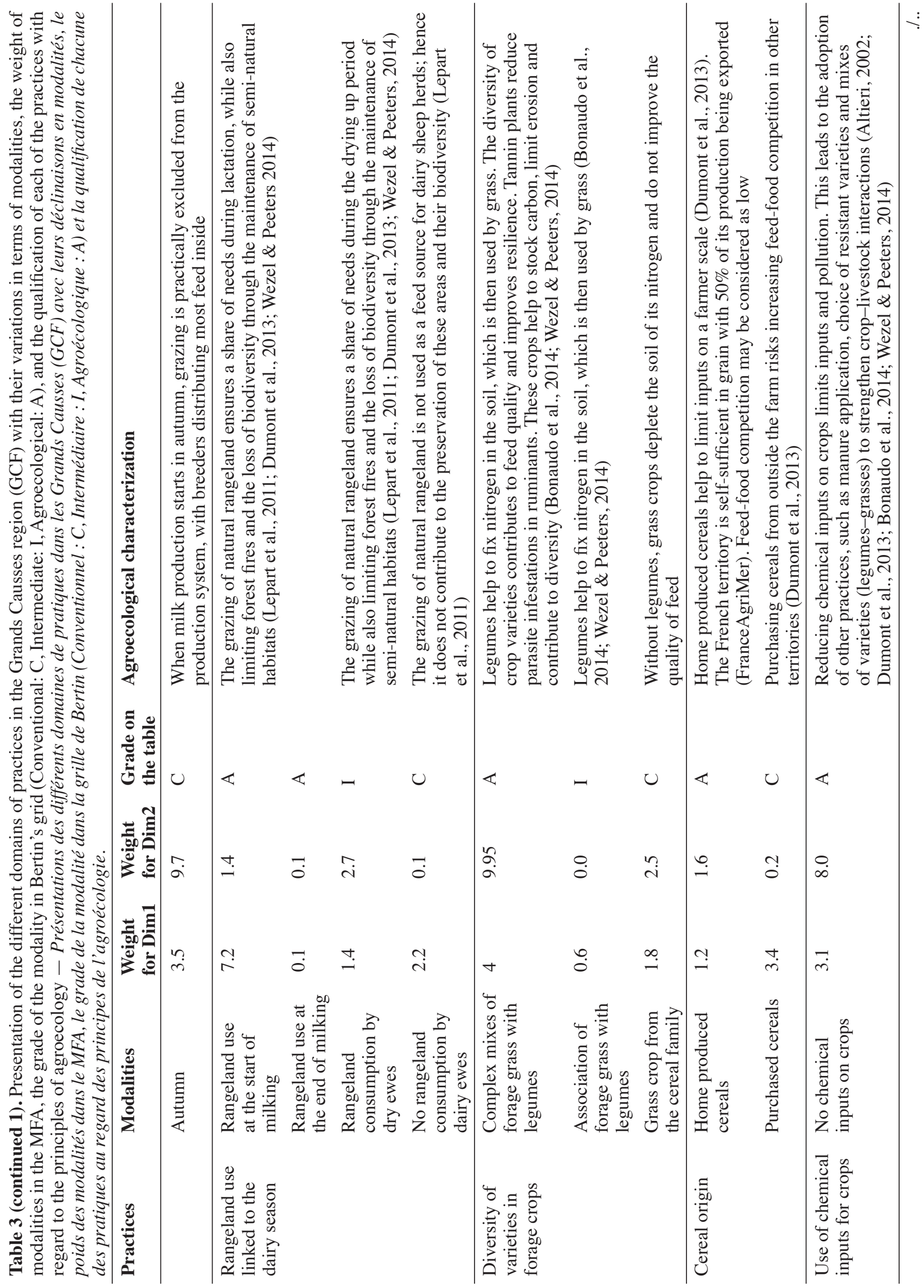




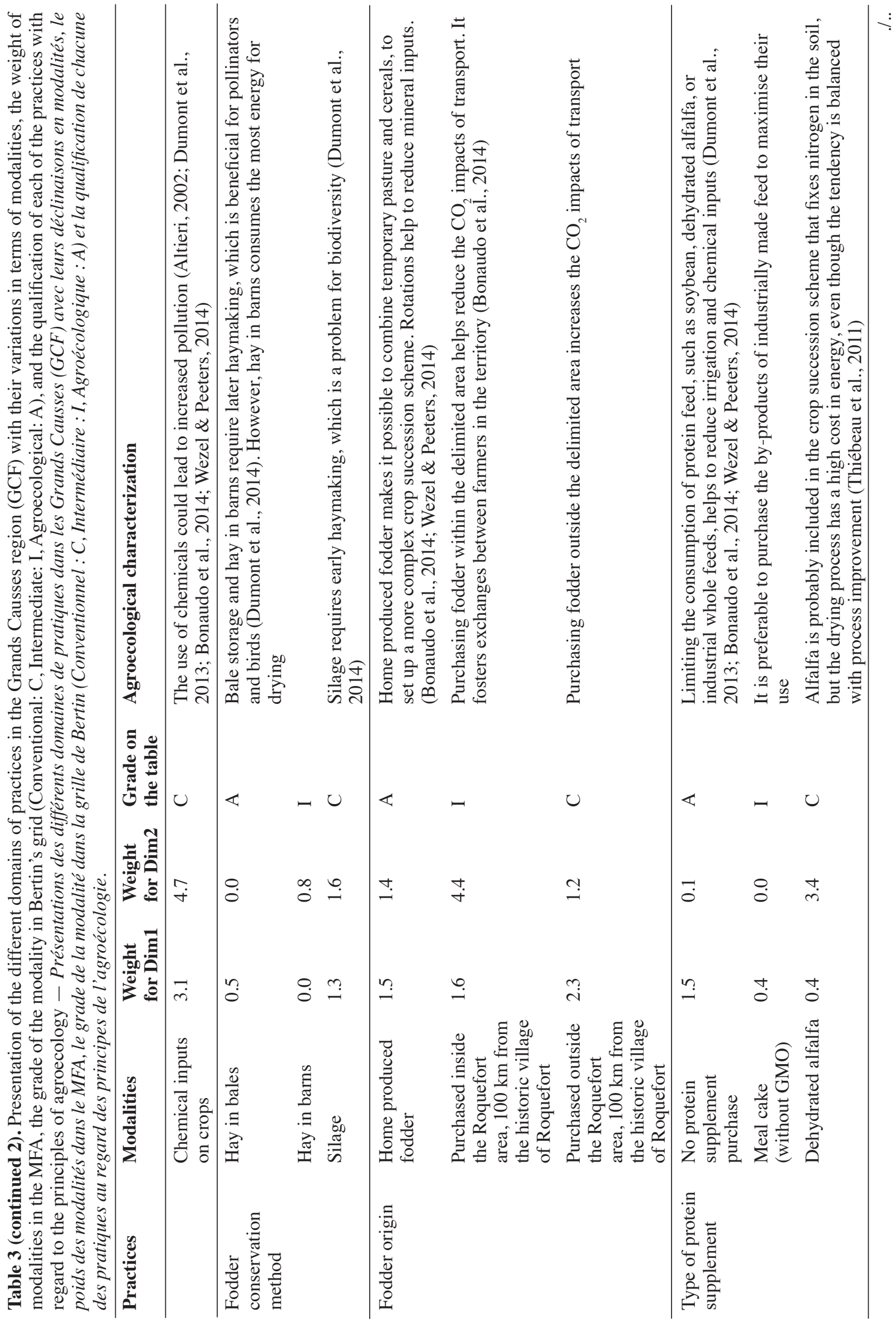



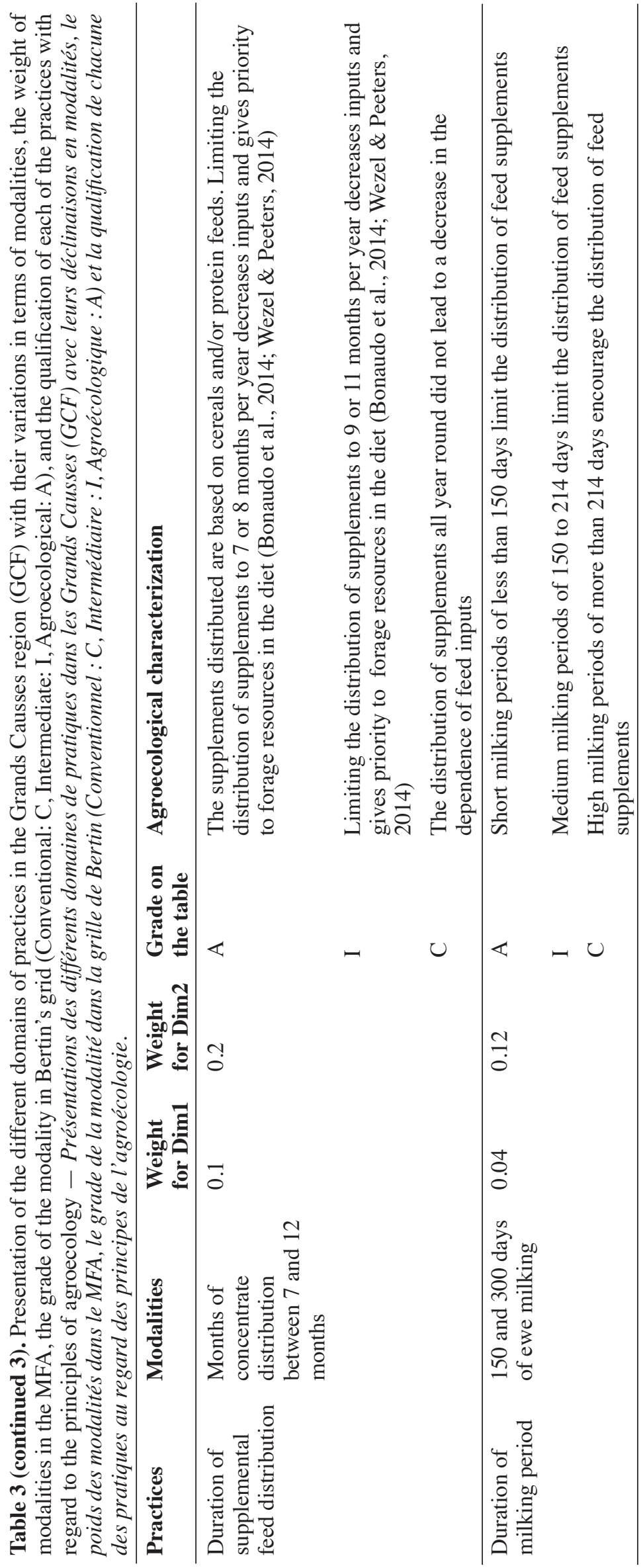

reproductive, feeding, rangeland, milking, cropping, input. For WBF, the practices were: feeding, grazing, reproductive, breeding, forage, input, infrastructure. We qualified these types of practices based on the five agroecological principles. The modalities of practices, which differed from one trajectory to another, led us to characterize within-group homogeneity and between-group variability. We used multiple factorial analyses (MFA) to obtain a summary of changes in practices for all farmers. Thus, we established a typology of trajectories grouping the farms according to size, orientation, and the proximity of the segments. All calculations were performed with $\mathrm{R}$ software, using FactoMineR for $\mathrm{WBF}$ and the additional library PCAmixdata for GCF (allowing us to analyze both qualitative and quantitative data). In the MFA, an individual corresponded to a farm at a given period. In order to give the same weight to each type of practice, we weighted the variables describing it by $1 / n_{i}$, with $n_{i}$ being the number of variables defining type $i$. When a group of practices (e.g. feed) was described by two variables, we assigned a weight of 0.5 to each of the variables. In the factorial plane (dimensions 1 and 2), we traced line segments between the two individuals representing a farm at period P1 and period P2. A segment represented the trajectory of changes in practices for a given farm. The segment length between $\mathrm{P} 1$ and P2 for one farm depended on the practice changes and on their relative contribution to axis construction. If several livestock farmers had made the same types of changes, the segments aligned in the same direction in the factorial plane. The modalities of variables that contributed most in the construction of the axes (contribution higher than the averaged contribution) were noted on the axes of the figures to explain modifications in practices between the start (P1) and the end points (P2). We then constructed a Bertin grid to describe each type of trajectory (Bertin, 1983). We assessed the tendency to move towards more conventional practices, or towards more agroecological practices, while comparing their position in $\mathrm{P} 1$ and $\mathrm{P} 2$. For each variable, we classified the modalities from the most conventional, corresponding to the dominant practices in the territories, or which followed conventional intensification, to the most 
Vidal A., Lurette A., Nozières M.-O. et al.

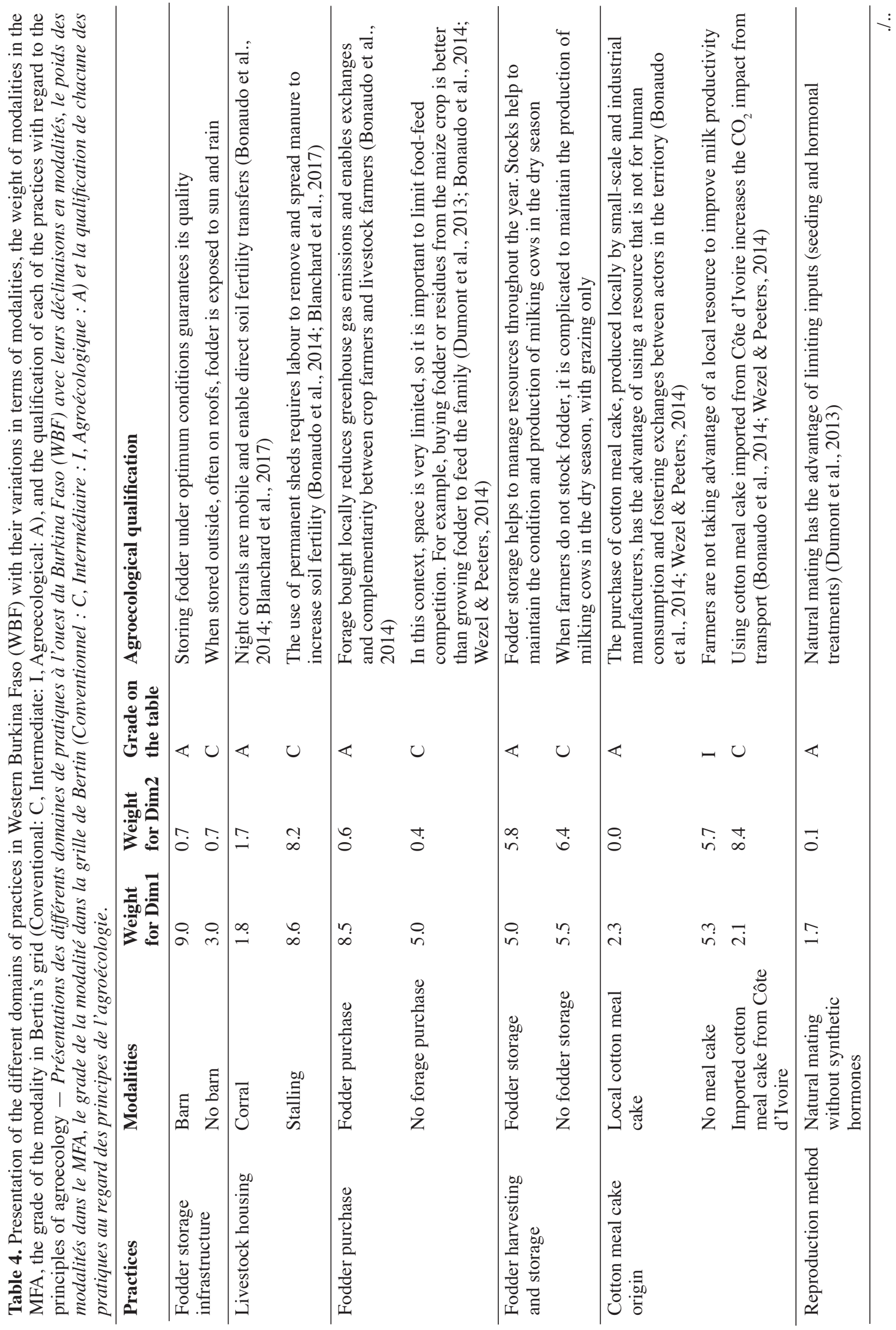




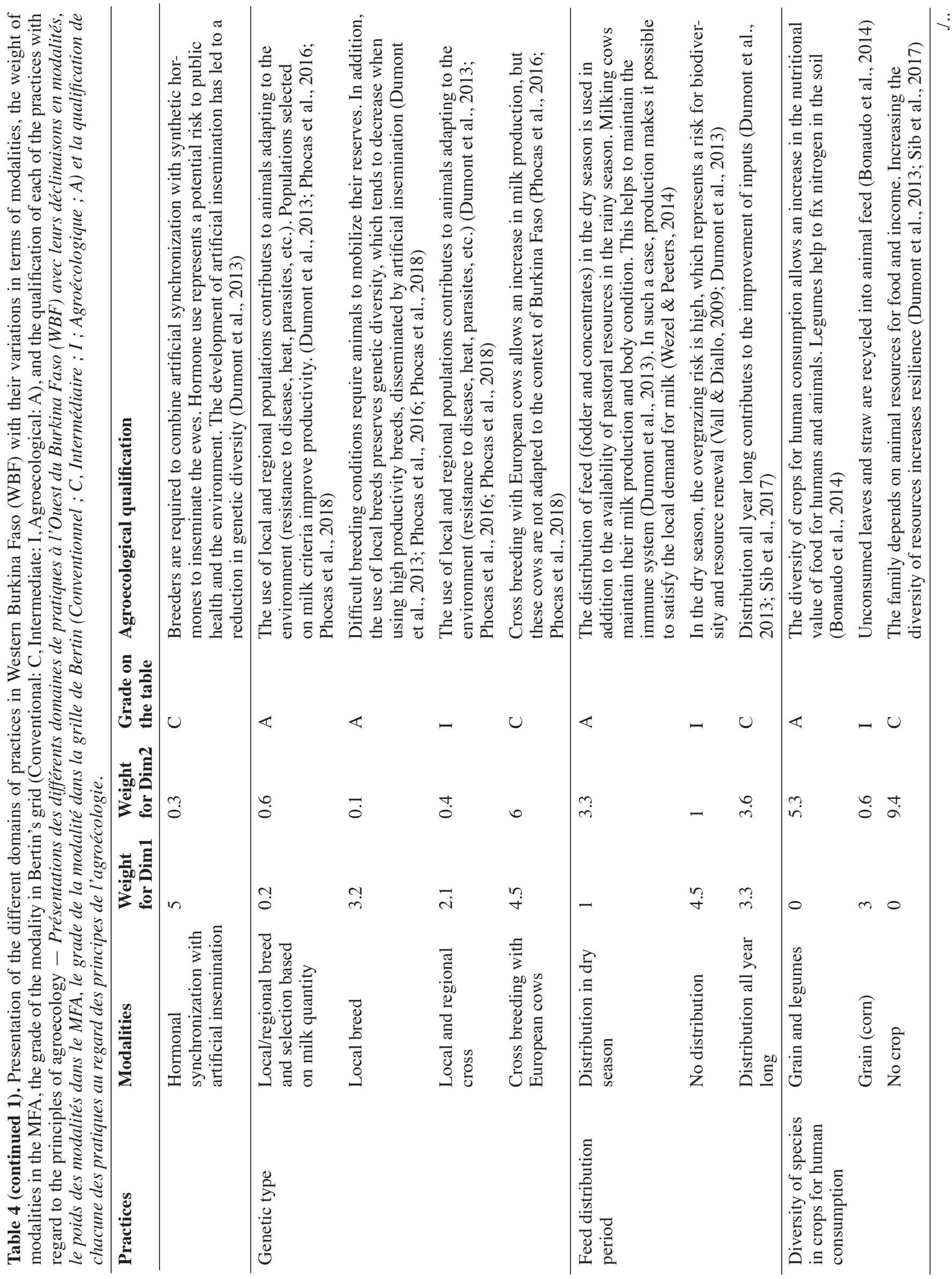


Vidal A., Lurette A., Nozières M.-O. et al.
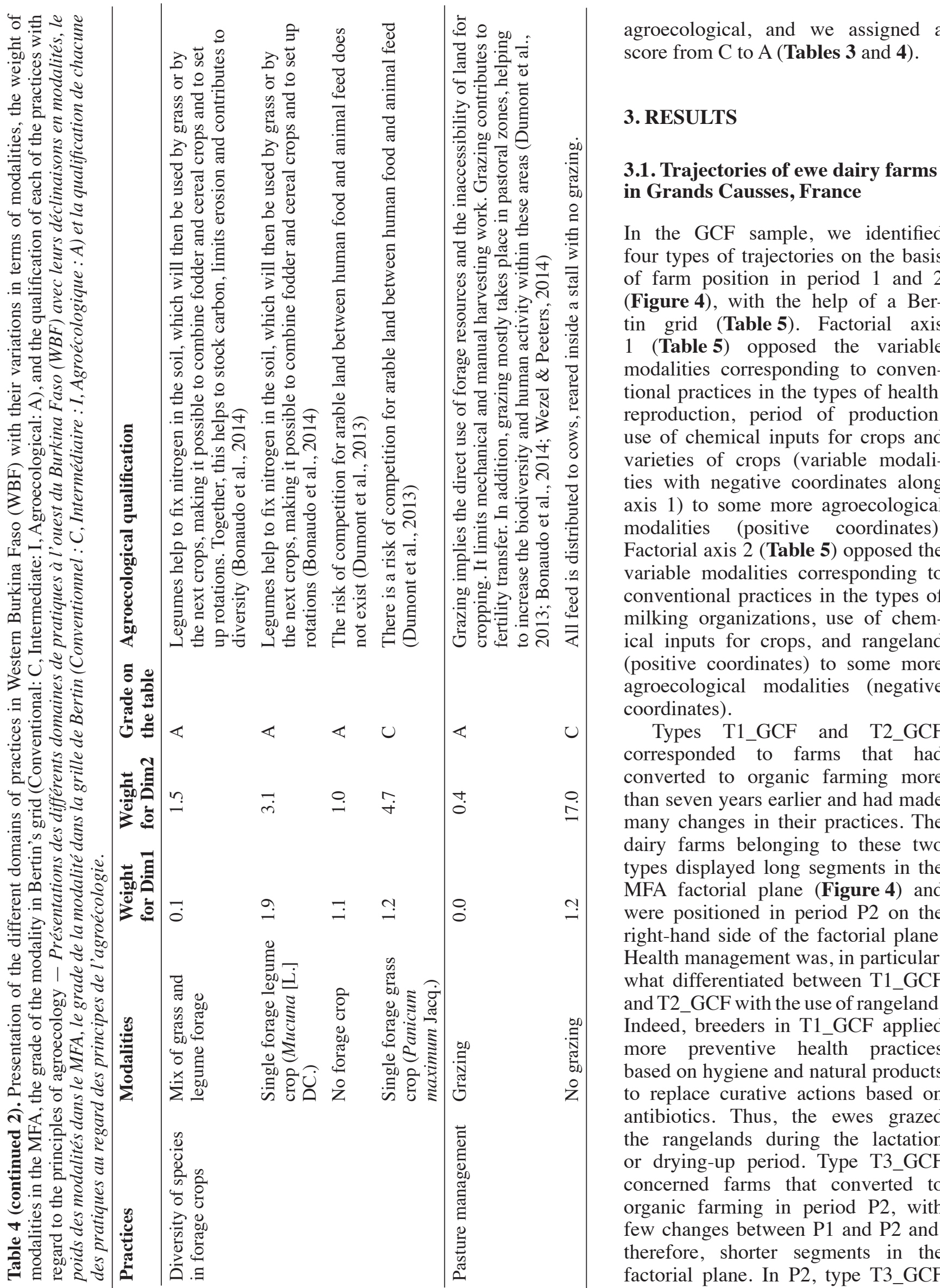

In the GCF sample, we identified four types of trajectories on the basis of farm position in period 1 and 2 (Figure 4), with the help of a Bertin grid (Table 5). Factorial axis 1 (Table 5) opposed the variable modalities corresponding to conventional practices in the types of health, reproduction, period of production, use of chemical inputs for crops and varieties of crops (variable modalities with negative coordinates along axis 1) to some more agroecological modalities (positive coordinates). Factorial axis 2 (Table 5) opposed the variable modalities corresponding to conventional practices in the types of milking organizations, use of chemical inputs for crops, and rangeland (positive coordinates) to some more agroecological modalities (negative coordinates).

Types T1_GCF and T2_GCF corresponded to farms that had converted to organic farming more than seven years earlier and had made many changes in their practices. The dairy farms belonging to these two types displayed long segments in the MFA factorial plane (Figure 4) and were positioned in period $\mathrm{P} 2$ on the right-hand side of the factorial plane. Health management was, in particular, what differentiated between T1_GCF and T2_GCF with the use of rangeland. Indeed, breeders in T1_GCF applied more preventive health practices based on hygiene and natural products to replace curative actions based on antibiotics. Thus, the ewes grazed the rangelands during the lactation or drying-up period. Type T3_GCF concerned farms that converted to organic farming in period $\mathrm{P} 2$, with few changes between P1 and P2 and, therefore, shorter segments in the factorial plane. In P2, type T3_GCF 


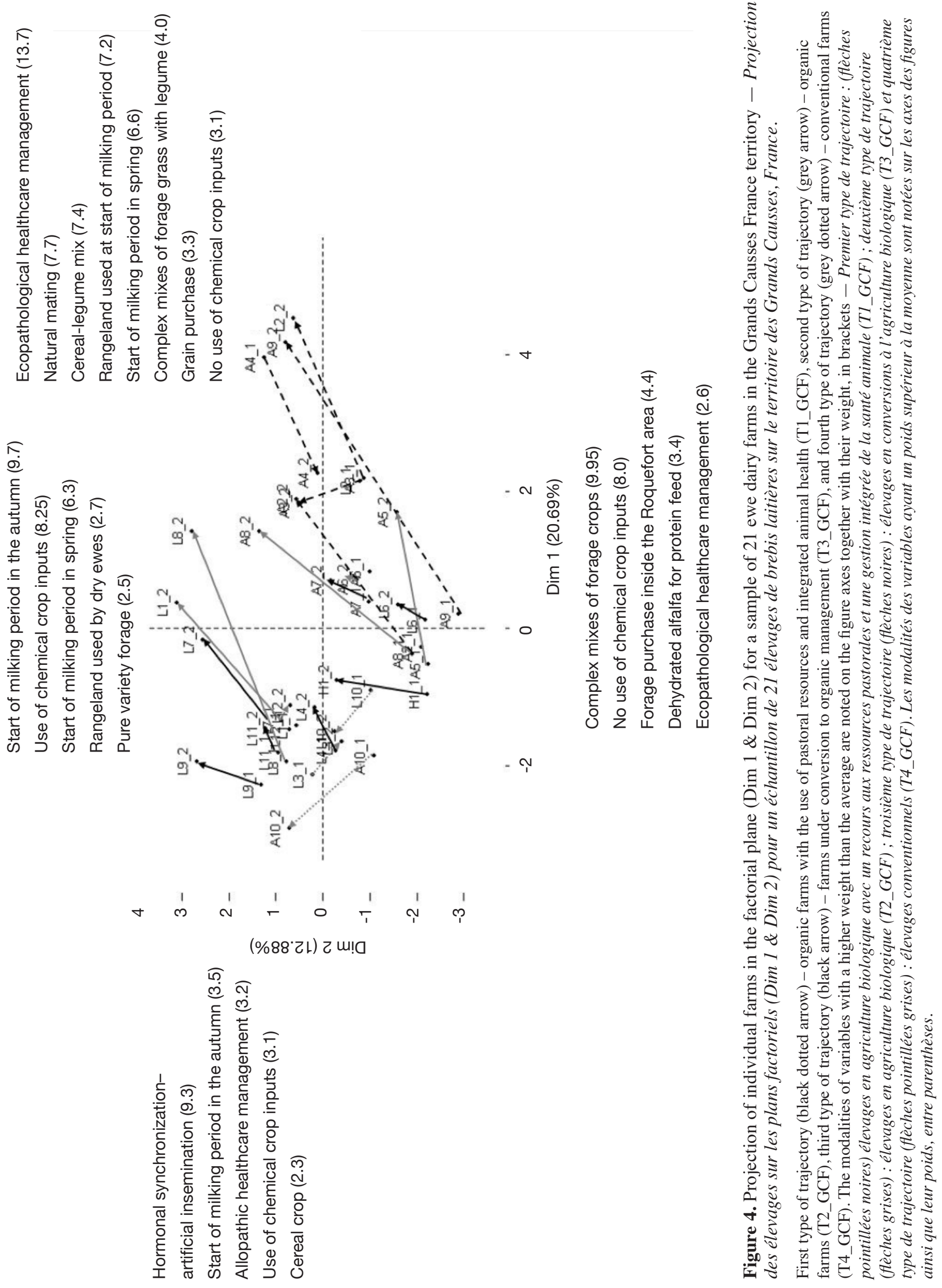


Table 5. Changes in practices between period $1(\mathrm{P} 1)$ and period $2(\mathrm{P} 2)$ in the trajectories in Grands Causses, France (GCF) on a scale from conventional practices (score C), intermediate practices (score I), to agroecological practices (score A). Trajectory 1 - T1_GCF, trajectory 2 - T2_GCF, trajectory 3 - T3_GCF and trajectory 4-T4_GCF - Changement des pratiques entre la période $1(P 1)$ et la période $2(P 2)$ dans les trajectoires des exploitations enquêtées dans les Grands Causses, France (GCF) sur une échelle allant des pratiques conventionnelles (score C), des pratiques intermédiaires (score I), aux pratiques agroécologiques (score A) : trajectoire 1 - T1_GCF, trajectoire 2 - T2_GCF, trajectoire 3 - T3_GCF et trajectoire 4 - T4_GCF.

\begin{tabular}{|c|c|c|c|c|c|c|c|c|c|c|}
\hline & \multicolumn{2}{|c|}{ T1_GCF } & \multicolumn{2}{|c|}{ T2_GCF } & \multicolumn{3}{|c|}{ T3_GCF } & \multicolumn{3}{|c|}{ T4_GCF } \\
\hline & $\mathbf{C}$ & $\mathbf{A}$ & $\mathbf{C}$ & A & $\mathbf{C}$ & $\mathbf{I}$ & $\mathbf{A}$ & $\mathbf{C}$ & $\mathbf{I}$ & A \\
\hline Healthcare practices & \multicolumn{2}{|r|}{$\mathrm{P} 1 \rightarrow \mathrm{P} 2$} & \multicolumn{2}{|r|}{$=$} & \multicolumn{3}{|c|}{$=$} & \multicolumn{3}{|l|}{$=$} \\
\hline Reproductive practices & \multicolumn{2}{|r|}{$=$} & \multicolumn{2}{|c|}{$\mathrm{P} 1 \longrightarrow \mathrm{P} 2$} & \multicolumn{3}{|l|}{$=$} & \multicolumn{3}{|l|}{$=$} \\
\hline Cereal-legume & \multicolumn{2}{|c|}{$\mathrm{P} 1 \longrightarrow \mathrm{P} 2$} & \multicolumn{2}{|l|}{$=$} & \multicolumn{3}{|l|}{$=$} & \multicolumn{3}{|l|}{$=$} \\
\hline Start of milking period & \multicolumn{2}{|r|}{$\mathrm{P} 1 \rightarrow \mathrm{P} 2$} & \multicolumn{2}{|r|}{$\mathrm{P} 1 \rightarrow \mathrm{P} 2$} & \multicolumn{3}{|c|}{$=$} & \multicolumn{3}{|c|}{$\mathrm{P} 2 \leftarrow \mathrm{P} 1$} \\
\hline Rangeland consumption linked to the dairy season & \multicolumn{2}{|r|}{$=$} & \multicolumn{2}{|r|}{$\mathrm{P} 2 \leftarrow \mathrm{P} 1$} & \multicolumn{3}{|c|}{$\mathrm{P} 2 \leftarrow \mathrm{P} 1$} & \multicolumn{3}{|c|}{$\mathrm{P} 2 \leftarrow \mathrm{P} 1$} \\
\hline Diversity of varieties in forage crops & \multicolumn{2}{|c|}{$\mathrm{P} 1 \longrightarrow \mathrm{P} 2$} & \multicolumn{2}{|r|}{$\mathrm{P} 1 \rightarrow \mathrm{P} 2$} & \multicolumn{3}{|c|}{$\mathrm{P} 1 \rightarrow \mathrm{P} 2$} & \multicolumn{3}{|l|}{$=$} \\
\hline Use of chemical inputs for crops & \multicolumn{2}{|c|}{$\mathrm{P} 1 \longrightarrow \mathrm{P} 2$} & \multicolumn{2}{|c|}{$\mathrm{P} 1 \longrightarrow \mathrm{P} 2$} & \multicolumn{3}{|c|}{$\mathrm{P} 1 \longrightarrow \mathrm{P} 2$} & \multicolumn{3}{|l|}{$=$} \\
\hline Forage conservation method & \multicolumn{2}{|r|}{$=$} & \multicolumn{2}{|c|}{$\mathrm{P} 2 \longleftarrow \mathrm{P} 1$} & \multicolumn{3}{|c|}{$\mathrm{P} 2 \longleftarrow \mathrm{P} 1$} & \multicolumn{3}{|c|}{$\mathrm{P} 2 \longleftarrow \mathrm{P} 1$} \\
\hline Forage origin & & $\mathrm{P} 2 \leftarrow \mathrm{P} 1$ & & $=$ & & & $=$ & & & $=$ \\
\hline Cereal origin & & $\mathrm{P} 2 \leftarrow \mathrm{P} 1$ & & $=$ & & & $=$ & & & $=$ \\
\hline Type of protein supplement & & $=$ & & $=$ & & $=$ & & & $=$ & \\
\hline Duration of supplemental feed distribution & & $\mathrm{P} 2 \leftarrow \mathrm{P} 1$ & $=$ & & $=$ & & & $=$ & & \\
\hline Duration of milking period & & $=$ & & $=$ & & $=$ & & $=$ & & \\
\hline
\end{tabular}

had positive coordinates along axis 1, towards the more agroecological modalities. Lastly, type T4_GCF corresponded to conventional farms. They had made a few changes in practices (short segments) in various directions. The length of the segments reflected the importance of the changes in practices that the farmer had made.

In trajectory type 1 (T1_GCF) $(n=5)$, during the already old conversion to organic farming, the farmers had adopted a set of agroecological modalities (Table 5) to sell organic milk. In period 1, before the conversion, some practices were already implemented according to agroecological modalities, such as natural mating without synthetic hormones, or the use of rangelands at different production periods (start and end of lactation, end of lactation). Between period 1 and period 2, the farmers adopted integrated healthcare practices. These practices limited allopathic interventions (antibiotics), preferring ecopathological practices designed to limit the occurrence of health problems by combining different means of prevention, from farm building hygiene to alternative medicines, such as essential oils, or grazing on tannin rich plants, such as sainfoin to limit parasitism. They had stopped using chemical inputs for crops. They had implemented greater diversity with complex legume-based mixes in fodder crops, and protein crops (vetch, peas, etc.) in cereals. These farmers were not self-sufficient in fodder and grain.

In type $2\left(\mathrm{~T} 2 \_\mathrm{GCF}\right)(n=5)$, all the farms had also converted to organic farming more than seven years previously to sell organic milk. However, T2_GCF had not adopted the same practices as T1_GCF (Table 5). They had made the changes to respect organic farming specifications. For instance, the dairy farmers had abandoned hormonal synchronization, artificial insemination and use of chemical inputs for crops and systematic allopathic treatments were limited. The farmers had adopted mixes of species for fodder crops. While some farmers only grew cereals, others had combined cereals with legumes. Rangeland use varied greatly, depending on the farmers in this type, with one of the five farmers having abandoned rangeland grazing. These farmers were self-sufficient in fodder and grain.

In type 3 (T3_GCF) $(n=7)$, all the farms had converted to organic farming in period 2 to sell organic milk. The conversion period was two years for crops, while it was only six months for livestock (Table 5). Thus, these farmers had stopped using chemical inputs on crops, but had maintained their reproduction practices, notably artificial insemination, leading to an incomplete conversion of their livestock farm. Regarding healthcare practices, the farmers had already 
adopted the targeted practices in P1. These farmers had tended to abandon fodder cropping of a single variety to grow combinations (legumes-grasses), or complex mixtures. Rangeland use had not changed between periods 1 and 2, but some farmers had already stopped using rangeland in period 1.

The farmers of the fourth type of trajectory (T4_GCF) $(n=4)$ remained with conventional agriculture. The organization of work, in particular to avoid competition between fieldwork and the herd, led farmers to change their milking period. The flexibility of dairy rules regarding the production period facilitated this change. However, they did use some agroecological practices, such as not abandoning rangelands (Table 5), but they used them at the end of the milking period, or their use was moved from the end of the milking period to the drying-up period, meaning that pastoral resources had limited value to feed the flock. Among these farmers, the tendency was to maintain the use of artificial insemination for reproduction. Healthcare practices remained allopathic with systematic treatments, or with targeted practices according to analysis results. Cropping practices continued to rely on chemical inputs. These farmers continued to grow single variety cereals, while grass-legume combinations or complex mixes were sometimes used to sow cultivated grasslands.

\subsection{Trajectories of dairy cattle farmers in Western Burkina Faso}

In the WBF sample, we identified four types of trajectories on the basis of farm position in period 1 and 2 (Figure 5), with the help of a Bertin grid (Table 6). In fact, factorial axis 1 opposed the variable modalities corresponding to traditional practices in the types of feed, structure, reproduction and genetics (negative coordinates) to some more specialized modalities in milk production (positive coordinates). Factorial axis 2 opposed the variable modalities corresponding to conventional practices in the types of grazing, crops, structure, genetics and feed (positive coordinates) to some practices of more agroecological modalities (negative coordinates).

Types T1_WBF and T2_WBF corresponded to very similar livestock farmers in period P1, with dairy farming relying on the grazing of highly diversified resources, including rangelands and cultivated fields in which crop residues remained in the dry season, with milking in the rainy season. These farmers had made some major changes (long segments, see Figure 5), leading to more agropastoral forms of livestock farming (crop residue storage, distribution of concentrates and fodder to sustain milk production in the dry season). Trajectory type T3_WBF corresponded to farmers who had also made some major changes. These dairy farms were quite diverse in $\mathrm{P} 1$, in pastoral or already more agropastoral situations. Now, they converged towards a similar operation in P2 (Figure 5). They had notably invested in infrastructure (cowsheds), used for cows with a higher milk potential, with feed distribution throughout the year to sustain milk production, in addition to grazing. Lastly, type T4_WBF4 corresponded to a type of intensified milk production, with livestock housing evolving towards a permanent indoor system.

In the first type of trajectory (T1_WBF) $(n=7)$, the dairy farmers had changed their feeding practices in order to produce milk all year round to supply a dairy processor. In period 1, they mainly used grazing of rangelands, with high herd mobility. Between period 1 and 2, the farmers continued to grow cereal crops for human consumption and they recycled straw for the cows. In period 2, the farmers had started to store various types of fodder in bales. In order to maintain milk production during the dry season, milking cows were grouped together to receive supplemental fodder (cereal straw, legume haulms or dried bush straw) and concentrates (bran, cotton cakes, or brewers' grain), in addition to grazing. The rest of the herd was transhumant. In the rainy season, the resources removed from pastures remained the only feed for milking cows. In this type of trajectory, the farmers maintained some agroecological practices (Table 6).

In the second type of trajectory (T2_WBF) $(n=8)$, the dairy farmers had adopted the same changes in feeding practices as in the first type, but they had also adopted other reproduction practices in order to produce all year round for a dairy. To complete their fodder stocks, they had begun to buy additional fodder resources. They had also invested in sheds for better conservation of their stored fodder. The farmers recycled crop residues, such as corn straw or bean leaves, for distribution to cows. In period 2, some farmers $(n=4)$ cultivated forage such as Panicum maximum Jacq. or Mucuna pruriens (L.) DC. Apart from these feeding changes, the farmers had also changed their genetic practices to improve their cows' milk production potential. For example, they kept bulls whose mothers had quantitatively better milk production as reproducers, or used regional breeds (Goudali) reputed for their better milk production. Some also carried out crosses with exotic dairy breeds (Holstein, Brune des Alpes, Tarentaise). These numerous changes in practices (Table 6) involved either adopting more agroecological modalities or, conversely, abandoning certain agroecological modalities.

The third type of trajectory (T3_WBF) $(n=4)$ corresponded to dairy farmers who had invested in milk production, generally investing capital from another activity (trader, male nurse, civil servant, etc.). This type had long been selling milk to dairies, but was 
Vidal A., Lurette A., Nozières M.-O. et al.

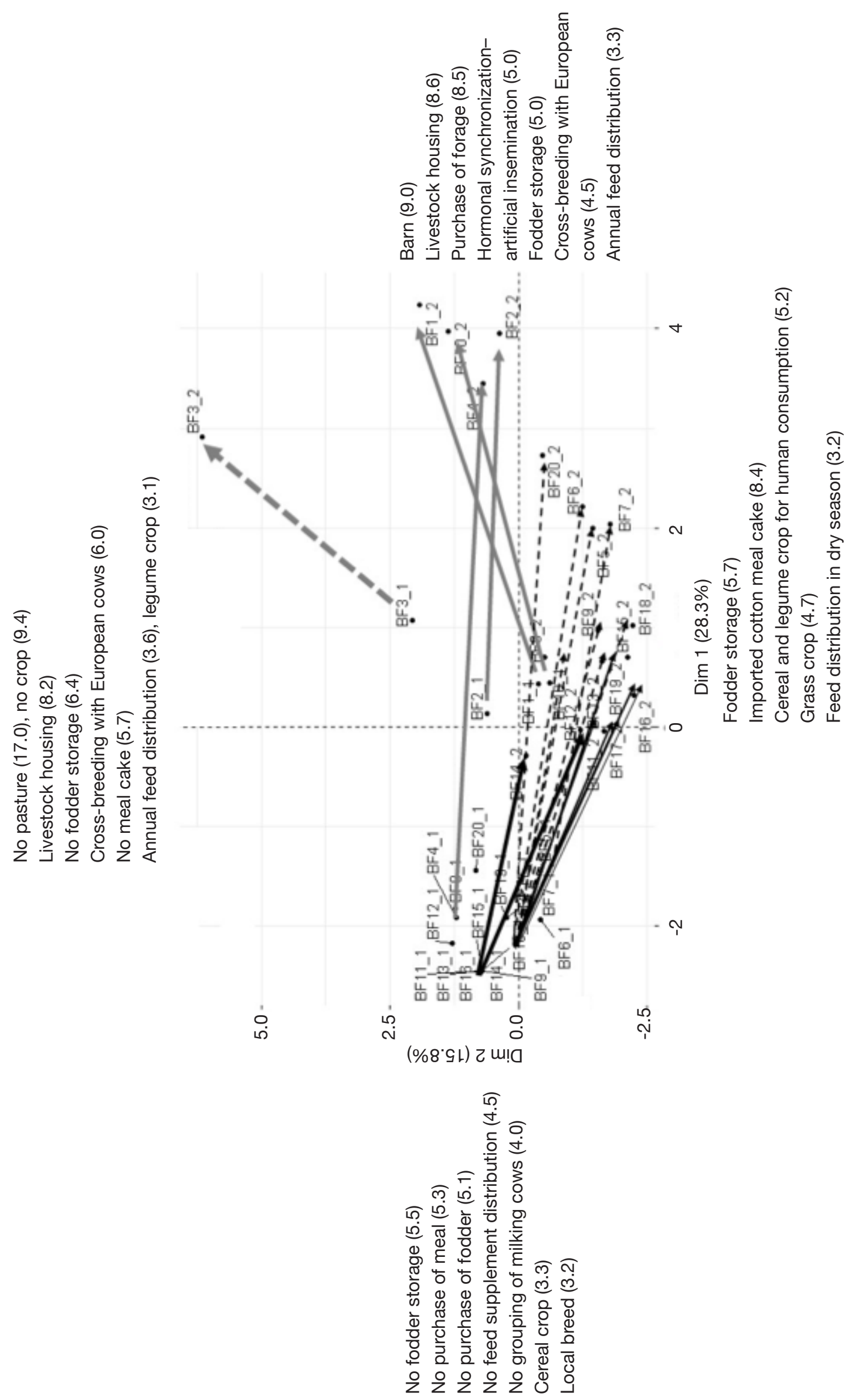

त $=0$ \%

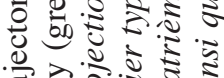

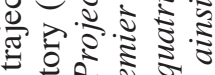

प. 0

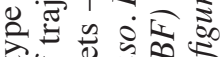

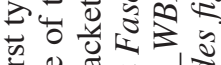

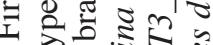

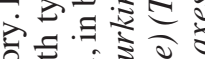

을

कृ.

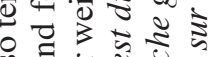

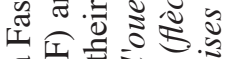

$\because$

430

ติ

表专:

कू.

उ

ข ब

छ

है 300.0

든

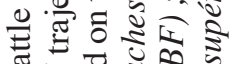

范

(1)

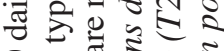

ㄷำ

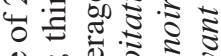

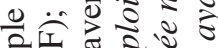

㲾

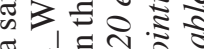

ำ 들

สิ

7.

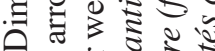

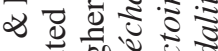

च 윰

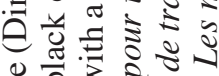

远的

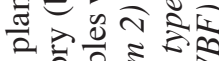

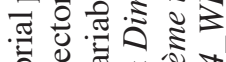

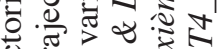

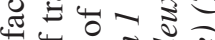

प

巳

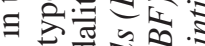

능 च 0

웡

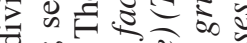

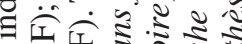

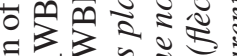

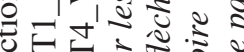

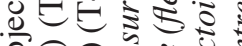

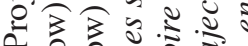

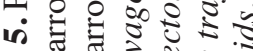

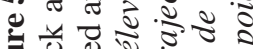

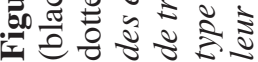


Table 6. Changes in practices between period $1(\mathrm{P} 1)$ and period $2(\mathrm{P} 2)$ in the trajectories of the farms surveyed in Western Burkina Faso (WBF) on a scale from conventional practices (score C), intermediate practices (score I), to agroecological practices (score A). Trajectory 1 - T1_WBF, trajectory 2 - T2_WBF, trajectory 3 - T3_WBF and trajectory 4 - T4_ WBF - Évolution des pratiques entre la période $1(P 1)$ et la période $2(P 2)$ dans les trajectoires des fermes de l'ouest du Burkina Faso (WBF) sur une échelle allant des pratiques conventionnelles (score C), des pratiques intermédiaires (score I), aux pratiques agroécologiques (score A). Trajectoire 1 - T1_WBF, trajectoire 2 - T2_WBF, trajectoire 3 - T3_WBF et trajectoire 4 - T4_WBF.

\begin{tabular}{|c|c|c|c|c|c|c|c|c|c|c|c|c|}
\hline & \multicolumn{3}{|c|}{ T1_WBF } & \multicolumn{3}{|c|}{ T2_WBF } & \multicolumn{3}{|c|}{ T3_WBF } & \multicolumn{3}{|c|}{ T4_WBF } \\
\hline & $\mathbf{C}$ & $\mathbf{I}$ & $\mathbf{A}$ & $\mathbf{C}$ & I & $\mathbf{A}$ & C & I & $\mathbf{A}$ & $\mathbf{C}$ & I & $\mathbf{A}$ \\
\hline Forage storage infrastructure & $=$ & & & $\mathrm{P} 1$ & & $\mathrm{P} 2$ & & & $=$ & & & $=$ \\
\hline Livestock housing & & & $=$ & & & $=$ & $\mathrm{P} 2$ & 4 & $\mathrm{P} 1$ & $=$ & & \\
\hline Fodder purchase & $=$ & & & $\mathrm{P} 1$ & & $\mathrm{P} 2$ & & & $=$ & & & $=$ \\
\hline Fodder harvesting and storage & $\mathrm{P} 1-$ & & $\mathrm{P} 2$ & $\mathrm{P} 1$ & & $\mathrm{P} 2$ & $\mathrm{P} 1$ & $\longrightarrow$ & $\mathrm{P} 2$ & $=$ & & \\
\hline Cotton meal cake origin & $\mathrm{P} 2 \leftarrow$ & & & $\mathrm{P} 2$ & & & & & $=$ & $=$ & & \\
\hline Reproduction method & & & $=$ & $\mathrm{P} 2$ & & $\mathrm{P} 1$ & $\mathrm{P} 2$ & 4 & $\mathrm{P} 1$ & $=$ & & \\
\hline Genetic type & & & $=$ & & & $-\mathrm{P} 1$ & $\mathrm{P} 2$ & $\leftarrow$ & $\mathrm{P} 1$ & $\mathrm{P} 2$ & & \\
\hline Feed distribution period & & & $\rightarrow \mathrm{P} 2$ & & & $\mathrm{P} 2$ & $\mathrm{P} 2$ & 4 & P1 & $\mathrm{P} 2$ & & $\mathrm{P} 1$ \\
\hline Diversity of species in crops for human consumption & & & $\rightarrow \mathrm{P} 2$ & & & $\mathrm{P} 2$ & & & $\mathrm{P} 2$ & $=$ & & \\
\hline Diversity of species in forage crops & & $=$ & & $=$ & & & & & $\mathrm{P} 2$ & & $=$ & \\
\hline Pasture management & & & $=$ & & & $=$ & & & $=$ & $=$ & & \\
\hline
\end{tabular}

forced to find new markets after the closure of the public dairies. They had acquired the land on which the farms were established with part of their pasture. Then, they invested in infrastructures (livestock housing, storage shed, etc.) and in herd genetics. They started crossing their cattle with European dairy breeds, using hormonal synchronization and artificial insemination. Feeding practices shifted from seasonal fodder and concentrate supplementation during the dry season, in addition to pasture, towards supplemental feeding throughout the year. In period 2, the majority of farmers $(n=3)$ cultivated forage such as $P$. maximum or $M$. Pruriens. This type of trajectory was characterized by the abandonment of several agroecological modalities, but the adoption of others (Table 6).

The fourth type of trajectory (T4_WBF) $(n=1)$ traced the changes in practices in a very urbanized zone, where the farmers had been selling milk for a long time to a dairy. Accessibility to pasture gradually decreased with urbanization and the classification of forest as a protected zone. This led to a suppression of grazing. Farmers kept cows in a yard under shelter. Initially the herd contained cows of the Goudali breed with a view to supplying the nearby dairy throughout the year. The farmers inseminated their cows to produce crosses with European breeds. The feed of the half-breed cows was totally purchased and came from industrial by-products (cotton husks), food waste (cabbage leaves), or fresh grass sold in town. This type of trajectory corresponded to conventional intensification of milk production, based on inputs purchased to feed housed cows with good potential. The agroecological modalities used in period 1 were largely abandoned (Table 6).

\section{DISCUSSION}

Faced with biophysical and socio-economic changes in their environment, notably through the demands of dairies, farmers have adapted livestock management and cropping practices. While the two samples were limited in size, they did reveal a diversity of trajectories of changes in practices. However, the samples did not guarantee an exhaustive picture of the types of trajectories and did not bring out their relative importance within the population. Moreover, the link between the change in dairy or production season, and the change in practices, was difficult to establish because of the length of time between the two periods studied. Nonetheless, this study provided knowledge about eight current trajectories and showed how they are, or not, in line with agroecological practices.

The trajectories involved in agroecological transition in France appear to be structured around the organic farming label. However, we found two trajectories. In the T1_GCF trajectory, farmers applied a set of practices based on agroecological principles while making use of pastoral resources. However, these farming systems were not self sufficient in feed. In 
contrast, the livestock farming systems of the T2_GCF trajectory were self-sufficient in terms of animal feed. The latter did not make use of pastoral resources. The two trajectories T1_GCF and T2_GCF corresponded to a conversion to organic farming more than seven years earlier. In trajectory T1_GCF, the farmers adopted twelve agroecological practices. Trajectory T2_GCF showed that the application of organic farming specifications did not necessarily commit livestock farmers to completely redeveloping their system based on agroecology principles. Van Dam \& Nizet (2012) spoke of the institutionalization, or conventionalization, of organic farming to standardize organic products on the grounds of market pressure. This process strengthened some industrialization and commodification principles, but they were combined with certain ecological references. The authors highlighted that this phenomenon was a second observed evolution of organic production that responds to trade-offs. As shown in trajectory T2 GCF, the farmers changed some practices for others corresponding to organic rules, but did not change all their practices like T1_GCF. Organic farming corresponds to a diversity of reality (Allaire, 2016). Conversion to organic farming suggests that trajectory T3_GCF was in a phase of ongoing transformation, suggesting a change in practices towards the adoption of agroecological practices, notably abandoning synthetic inputs in favor of cycle closing. On the other hand, trajectory T4_GCF showed that remaining with conventional farming was compatible with the adoption of two out of thirteen agroecological practices. According to Quetier et al. (2005), the specifications of the Roquefort Protected Designation of Origin (PDO) have played a role in committing the dairy farmers in the territory to continue using rangelands. Over the medium term, it could be imagined that the Roquefort PDO might strengthen its specifications to include more agroecology principles, as under certain winegrowing PDOs (Gautier, 2016). As with PDOs and organic farming labels, agroecological farming is subject to different visions (Cayre et al., 2018).

In Western Burkina Faso, our sample highlighted four trajectories for farms supplying milk to the local market. In Burkina Faso, we observed two agroecological transition trajectories (T1_WBF and T2_WBF). These two trajectories had livestock systems that had shifted from extensive production systems to production systems favoring crop-livestock integration. These new farming systems relied on locally produced resources from agriculture and industry that were not consumed by humans.

To enable more milk to be delivered in the dry season, the changes made remained well within an agroecological framework for trajectories T1_WBF et T2_WBF (Dumont et al., 2013). Farmers used feed inputs that were mostly produced locally (Sib et al., 2017), enhancing biomass flows at territorial level (Dumont et al., 2013) by crop-livestock integration (Bonaudo et al., 2014). In trajectories T1_WBF and T2_WBF, the farmers were traditional breeders who used low inputs (Hamadou et al., 2004; Sib et al., 2017). In trajectory T3_WBF and T4_WBF, the farmers specialized in milk (Hamadou et al., 2004; Sib et al., 2017). Before changing practices, T3_WBF farmers applied a set of agroecological practices, but breeding practices involved crosses with exotic breeds and reproduction by hormonal synchronization and insemination for an intensification of production. Such practices entailed uncertainties about the ability of animals to adapt to tropical conditions (Phocas et al., 2016). Crossing between local animal populations and exotic dairy breeds would need to be accompanied by genetic improvement programs, in order to produce animals adapted to local environmental conditions and to low-input production systems (Phocas et al., 2018). The second noteworthy fact is that trajectory T4_WBF farmers had abandoned grazing. This illustrates the problem of securing land and farmers' accessibility to pastoral areas to allow animals to graze in West Africa (Gonin \& Tallet, 2012).

The comparative analysis of the trajectories in the two study areas showed that changes in agropastoral dairy systems took place under different constraints that did not always lead to an increase in agroecological practices in agropastoral dairy farming systems. Our normative approach was a social and scientific construction according to an agroecology analysis framework (Altieri, 2002; Dumont et al., 2013), which enabled us to identify trajectory types and qualitatively assess their engagement in agroecological transition. However, the context played a major role in understanding the trajectories. Land challenges do not take on the same meaning in West Africa and Europe. Human pressure (Dongmo et al., 2007) on agropastoral resources leads livestock farmers to adopt intensification practices in WBF (Vall et al., 2006). The development of fodder crops exclusively for animal feed is limited by access to land and competes with food crops (César et al., 2004). These constraints have led dairy farmers to buy feed inputs to produce milk and earn a higher income. Nevertheless, these livestock systems use local resources (Sib et al., 2017). Crop-livestock integration seems to be a sustainable pathway (Dugué et al., 2012). For European countries, with farms being abandoned, rangelands are gradually being deserted. There are stakes in reconquering these areas (Lepart et al., 2011). In the trajectories identified here, rangeland use varied from one farm to another, from maintaining pastoral practices and feed resources, right up to their abandonment. The abandonment or under-use of rangelands is a risk for the closure of 
pastoral areas, with the development of forest, and threatens a share of biodiversity (Lepart et al., 2011), even though they were originally man-made. The return of wolves to the territory casts doubts on these pastoral practices (Meuret et al., 2017).

The issue of food security is a major challenge that occurs differently in the two study areas. In Western Burkina Faso, food security challenges are reflected in the need to increase milk production, but also to diversify food commodities (Lourme-Ruiz et al., 2016). The dairy farmers introduce practices to support family consumption and to supply the local dairies throughout the year. In the Grands Causses territory in France, food security issues concern health quality, traceability, but also the practices introduced by dairy farmers through signs of quality and origin, and supplying food (cheeses, ultra-fresh) for local consumption (Allaire \& Sylvander, 1997). In Europe, consumers contribute to changes in farming practices because they buy labelled or local products (Allaire, 2016). This comparison between the two territories shows that agroecological transition needs a strong structural support, such as market organization demanding high quality products that respect the environment. The WBF example shows that, without support, such as the organic referential in the GCF territory, or organization, the trend would be towards specialization in order to facilitate production and secure supplies to dairies.

\section{CONCLUSIONS AND PERSPECTIVES}

The emergence of novel trajectories provides food for thought for designing innovative systems. However, it would be worth making a quantitative assessment of how changes in practices affect farm performance and sustainability, depending on the technical and economic results achieved, and not only the means devoted by farmers via their practices. A comprehensive and understanding approach to transition would elucidate the issues raised by this study, especially how the process takes place and who the stakeholders involved in this agroecological transition are. Agroecological transition would benefit from being co-constructed, by taking into account the diversity of local contexts through research, in partnership with farmers, technical supervision, NGOs and policy makers.

\section{Bibliography}

Allaire G., 2016. Que signifie le «développement» de l'agriculture biologique ? Innovations Agron., 51, 1-17.

Allaire G. \& Sylvander B., 1997. Qualité spécifique et systèmes d'innovation territoriale. Cah. Écon. Sociologie Rurales, 44, 29-59.
Allézard V. et al., 2014. Foisonnement de l'innovation agricole: quelques exemples d'initiatives en élevage herbivore. Fourrages, 37-46

Altieri M.A., 2002. Agroecology: the science of natural resource management for poor farmers in marginal environments. Agric. Ecosyst. Environ., 93(1), 1-24, doi.org/10.1016/s0167-8809(02)00085-3

Bertin J., 1983. Semiology of graphics: diagrams, networks, maps. Madison, WI, USA: The University of Wisconsin.

Blanchard M., Vall É., Tingueri L.B. \& Meynard J.-M., 2017. Identification, caractérisation et évaluation des pratiques atypiques de gestion des fumures organiques au Burkina Faso : sources d'innovation? Autrepart, 81, 115-134, doi.org/10.3917/autr.081.0115

Bonaudo T. et al., 2014. Agroecological principles for the redesign of integrated crop-livestock systems. Eur. J. Agron., 57, 43-51, doi.org/10.1016/j.eja.2013.09.010

Capillon A. \& Tagaux M.-J., 1984. Évolution récente et diversité des exploitations agricoles du marais poitevin de Vendée. Bull. Techn. Inf., 389, 205-218.

Cayre P., Michaud A., Theau J.-P. \& Rigolot C., 2018. The coexistence of multiple worldviews in livestock farming drives agroecological transition. A case study in French Protected Designation of Origin (PDO) cheese mountain areas. Sustainability, 10(4), 1097, doi.org/10.3390/ su10041097

César J., Ehouinsou M. \& Gourou A., 2004. Production fourragère en zone tropicale et conseils aux éleveurs (Projet PROCORDEL). Bobo-Dioulasso, Burkina Faso : CIRDES ; Cotonou, Bénin : INRAB ; Montpellier, France : CIRAD Emvt.

Dongmo A.L. et al., 2012. Du nomadisme à la sédentarisation: l'élevage d'Afrique de l'Ouest et du Centre en quête d'innovation et de durabilité. Rev. Ethnoécologie, 1, 147-161, doi.org/10.4000/ ethnoecologie.779

Dongmo A.L. et al., 2007. L'espace est fini ! Vive la sédentarisation? Innovations et développement durable en question chez les pasteurs des zones cotonnières d'Afrique de l'ouest et du centre. In : 14è rencontres autour des recherches sur les ruminants, 5-6 décembre 2007, INRA, Institut de l'Élevage, Paris, France. Paris : Institut de l'Élevage, 153-160.

Dugué P. et al., 2012. L'intensification écologique : réflexions pour la mise en pratique de ce concept dans les zones de savane d'Afrique de l'Ouest. In : Actes du séminaire CIRAD ASAP, Partenariat, modélisation, experimentations : quelles leçons pour la conception de l'innovation et l'intensification écologique?, novembre 2011, Bobo-Dioulasso, Burkina Faso, 1-15.

Dumont B. et al., 2013. Prospects from agroecology and industrial ecology for animal production in the $21^{\text {st }}$ century. Animal, 7(06), 1028-1043, doi.org/10.1017/ s1751731112002418

Duteurtre G., 2007. Commerce et développement de l'élevage laitier en Afrique de l'Ouest : une synthèse. 
Rev. Élevage Méd. Vét. Pays Trop., 60(1-4), 209-223, doi.org/10.19182/remvt.9972

FAO, 2006. Livestock's long shadow environmental issues. Roma: FAO.

Ganière J.P. et al., 1991. L'écopathologie: une méthode d'approche de la santé en élevage. INRA Prod. Anim., 4(3), 247-256.

Gautier J., 2016. For better integration of the principles of agroecology in the specifications of French wine geographical indications / Pour une meilleure intégration des principes de l'agro-écologie dans les cahiers des charges des indications géographiques viticoles françaises. BIO Web Conf., 7, 03019, doi.org/10.1051/ bioconf $/ 20160703019$

Gerber P.J. et al., 2013. Tackling climate change through livestock: a global assessment of emissions and mitigation opportunities. Roma: FAO.

Gliessman S.R. \& Engles E.W., 2015. Agroecology: the ecology of sustainable food systems. Boca Raton, FL, USA: CRC Press, 371.

Gobindram N.-E. et al., 2018. Feeding flocks on rangelands: insights into the local ecological knowledge of shepherds in Boulemane province (Morocco). Rangeland J., 40(3), 207, doi.org/10.1071/rj17006

Gonin A. \& Tallet B., 2012. Spatial changes and pastoralist practices: new methods of transhumance in western Burkina Faso. Cah. Agric., 6, 448-454, doi.org/10.1684/ agr.2012.0595

Goodman L., 1961. Snowball sampling. Ann. Math. Stat., 32(1), 148-170.

Hamadou S., Marichatou H. \& Kamuanga M., 2004. Croissance désordonnée des élevages périurbains et approvisionnement de la ville de Bobo-Dioulasso. Études Rech. Sahéliennes, (8-9), 107-117.

Hamadou S., Tou Z. \& Toé P., 2008. Le lait, produit de diversification en zone périurbaine à Bobo-Dioulasso (Burkina Faso). Cah. Agric., 17(5), 473-478, doi. org/10.1684/agr.2008.0233

Ingrand S. et al., 2014. Le processus d'innovation en ferme. Illustrations en élevage. INRA Prod. Anim., 27(2), 147160.

Jouven M., dir., 2016. L'agroécologie. Du nouveau pour le pastoralisme? Die, France: Association française de Pastoralisme ; Avignon, France : Cardère éditeur.

Lacombe C., Couix N., Hazard L. \& Gressier E., 2018. L'accompagnement de la transition agroécologique: un objet en construction. Retour d'expérience d'une recherche-action avec une association d'éleveurs et de conseillers dans le Sud-Aveyron. Pour, 234-235(2-3), 217-223, doi.org/10.3917/pour.234.0217

Lepart J., Marty P. \& Fonderflick J., 2011. Dynamique des paysages agro-pastoraux des Causses et biodiversité. Fourrages, 208, 343-352.

Lourme-Ruiz A., Dury S. \& Martin-Prével Y., 2016. Consomme-t-on ce que l'on sème? Relations entre diversité de la production, revenu agricole et diversité alimentaire au Burkina Faso. Cah. Agric., 25(6), 1-11, doi.org/10.1051/cagri/2016038

Magne M.A., Cerf M. \& Ingrand S., 2010. A conceptual model of farmers' informational activity: a tool for improved support of livestock farming management. Animal, 4(6), 842-852.

Magne M.-A. et al., 2019. An integrated approach to livestock farming systems' autonomy to design and manage agroecological transition at the farm and territorial levels. In: Bergez J.-E., Audouin E. \& Therond O., eds. Agroecological transitions: from theory to practice in local participatory design. Springer International Publishing, 45-68.

Meuret M. et al., 2017. Élevage et loups en France: historique, bilan et pistes de solution. INRA Prod. Anim., 30(5), 465-478, doi.org/10.20870/productionsanimales.2017.30.5.2277

Meynard J.-M., 2017. L'agroécologie, un nouveau rapport aux savoirs et à l'innovation. $O C L, \mathbf{2 4}(3), \mathrm{D} 303$, doi. org/10.1051/ocl/2017021

Morin E., Astruc J.M., De Boissieu C. \& Lagriffoul G., 2016. Production de lait de brebis dans le rayon de Roquefort, quelles adaptations des systèmes d'élevage aux évolutions du contexte de la filière. In: Napoléone M. et al., eds. The value chains of Mediterranean sheep and goat products. Organisation of the industry, marketing strategies, feeding and production systems. Zaragoza, Spain: CIHEAM, 671-675.

Moulin C.-H. et al., 2008. Comprendre et analyser les changements d'organisation et de conduite de l'élevage dans un ensemble d'exploitations: propositions méthodologiques. In: Dedieu B. et al. L'élevage en mouvement. Flexibilité et adaptation des exploitations d'herbivores. Paris : Éditions Quæ.

Orasmaa T., 2017. Fostering locality in global value chains: potential of small-scale milk processors to increase local milk sourcing, create employment and reduce milk powder imports in Burkina Faso. Phd thesis: University of Copenhagen (Denmark).

Perrot C., Landais E. \& Pierret P., 1995. L'analyse des trajectoires des exploitations agricoles. Une méthode pour actualiser les modèles typologiques et étudier l'évolution de l'agriculture locale. Écon. Rurale, 228(1), 35-47, doi.org/10.3406/ecoru.1995.4744

Phocas F. et al., 2016. Review: towards the agroecological management of ruminants, pigs and poultry through the development of sustainable breeding programmes. II. Breeding strategies. Animal, 10(11), 1760-1769, doi. org/10.1017/s 1751731116001051

Phocas F. et al., 2018. Quels programmes d'amélioration génétique des animaux pour des systèmes d'élevage agro-écologiques ? INRA Prod. Anim., 30(1), 31-46, doi. org/10.20870/productions-animales.2017.30.1.2232

Quetier F., Marty P. \& Lepart J., 2005. Farmers' management strategies and land use in an agropastoral landscape: roquefort cheese production rules as a driver of 
change. Agric. Syst., 84(2), 171-193, doi.org/10.1016/j. agsy.2004.05.005

Sib O. et al., 2017. Production laitière à l'ouest du Burkina Faso dans un contexte d'émergence de laiteries : diversité des pratiques d'élevage et propositions d'amélioration. Rev. Élevage Méd. Vét. Pays Trop., 70(3), 81-91, doi. org/10.19182/remvt.31521

Soussana J.-F., Tichit M., Lecomte P. \& Dumont B., 2018. Agroecology: integration with livestock. In: Agroecology for food security and nutrition. Roma: FAO.

Stanton T.B., 2013. A call for antibiotic alternatives research. Trends Microbiol., 21(3), 111-113, doi.org/10.1016/j. tim.2012.11.002

Stassart P.M. et al., 2012. L'agroécologie : trajectoire et potentiel. Pour une transition vers des systèmes alimentaires durables. In : Agroécologie entre pratiques et sciences sociales. Dijon, France : Educagri Éditions.

Temple L. et al., 2015. Comparaison des trajectoires d'innovation pour la sécurisation alimentaire des pays du Sud. Biotechnol. Agron. Soc. Environ., 19, 53-61.

Thiébeau P., Hamerel T., Corson M. \& Gabrielle B., 2011. Carbon footprint of dehydrated lucerne production: recent progress due to changing harvest techniques and including wood chips as an energy source for drying. Impact on harvested forage quality. In: 18è rencontres autour des recherches sur les ruminants, 7-8 décembre 2011, INRA, Institut de l'Élevage, Paris, France. Paris : Institut de l'Élevage, 157-160.
Tittonell P., 2014. Ecological intensification of agriculturesustainable by nature.Curr. Opin.Environ. Sustainability, 8, 53-61.

Touzard J.-M. \& Temple L., 2012. Food securing and innovations in farming and the food industry. Towards a new research agenda? A review of the literature. Cah. Agric., 21(5), 293-301, doi.org/10.1684/agr.2012.0577

Vall É., Dugué P. \& Blanchard M., 2006. Le tissage des relations agriculture-élevage au fil du coton. Cah.Agric., 15(1), 72-79.

Vall É. \& Diallo M.A., 2009. Savoirs techniques locaux et pratiques : la conduite des troupeaux aux pâturages (Ouest du Brukina Faso). Nat. Sci. Soc., 17(2), 122-135, doi.org/10.1051/nss/2009024

Vall É. et al., 2014. Changements et innovations dans les systèmes d'élevage en Afrique. INRA Prod. Anim., 27(2), 161-174.

Van Dam D. \& Nizet J., 2012. Les agriculteurs bio deviennent-ils moins verts? In : L'agroécologie entre pratiques et sciences sociales. Dijon, France : Educagri Éditions, 249-264.

Wezel A. \& Peeters A., 2014. Agroecology and herbivore farming systems-principles and practices. Options Méditerr., 109, 753-768.

(54 ref.) 